\section{The Role of Educational Supervisors in Developinging the Professional Performance of Social Studies Teachers in

Jordan From a Teacher's \\ Perspective}

Maha Mohammad Mestarihi

Department of Educational Administration, Faculty of Education, University of Hail, KSA

Submitted: 17 September 2020

Accepted: 01 December 2020

Published: 31 December 2020

Corresponding author:

Maha Mohammad Mestarihi

DOI: 10.19044/esj.2020.v16n34p258

(c) Copyright 2020 Mestarihi M.M.

Distributed under Creative Commons BY-NC-ND 4.0 OPEN ACCESS

\section{Abstract}

This study aims to identify the role of the educational supervisors in developing the professional performance of social studies teachers in Jordan from a teacher's perspective in the Irbid Governorate of Jordan by identifying the effect of (gender, academic qualification, school level, and years of experience) variables during the academic year 2019/2020. The study used a descriptive and analytical approach on a sample consisted of (120) social studies teachers (60 teachers from each gender) selected randomly from a population of (690) teachers distributed over (487) government schools. A researcher-made questionnaire with (35) response-close questions divided into five areas: planning, teaching methods, relationship with colleagues and the local community, classroom visits, and evaluation on the five-point Likert scale was used as a measuring instrument, and its validity and stability were confirmed. The results showed that both genders agree that there is a major role for educational supervisors in developing the professional performance of social studies teachers, and there is a statistically significant impact at the level of significance $(\alpha \geq 0.05)$ attributable to gender variable in the areas of planning and teaching methods in favor of females. As well as, there is a statistically significant impact at the level of significance $(\alpha \geq 0.05)$ attributable to academic qualifications variable in the areas of planning and teaching methods in favor of postgraduate degree holders. The results also showed that there is an effective role of the educational supervisor in developing the professional performance of social studies

Mestarihi M.M., (2020). The Role of Educational Supervisors in Developinging the Professional Performance of Social Studies Teachers in Jordan From a Teacher's Perspective. European Scientific Journal, ESJ, 16(34), 258. https://doi.org/10.19044/esj.2020.v16n34p258 
teachers from teachers' perspective in Irbid Governorate of Jordan in the field of planning, relationship with colleagues and the local community in favor of primary schools, and no statistically significant impact of class visits, teaching methods and evaluation attributable to the school level variable. Also, there is a statistically significant impact at the level of significance $(\alpha \geq 0.05)$ attributable to years of experience in planning, teaching methods, and the relationship with colleagues and the local community in favor of the category (more than 10 years) of experience, and no statistically impact of classroom visits and evaluation attributed to years of experience variable.
In light of the results, the main recommendation was that, that there is a necessity for reviewing the supervision system by the Ministry of Education to reinforce the educational supervision system and increase the quality of education, thus, a new educational supervision model based on multiple data sources based on guidance should be developed and rapidly adapted to compete with the rapid changes occurring in the educational system, as well, technological and educational changes.

Keywords: Educational Supervisor, Professional Performance, Social Studies Teacher, Jordan

\section{Introduction}

Educational supervision function is one of the most important basic functions in the field of education, as it carries great importance in the process of developing and improving the educational learning process, by improving the level of teachers' performance in the field, in addition to evaluating all the elements of school education frameworks, especially, things do not remain static, and the wheels of change often take unexpected directions. The importance of educational supervision emerges from effective communication between four groups: the supervisor, the teacher, the student, and the school principal, if the relationship between them is solid that contains mutual trust, this leads to the improvement of the teaching and learning process, and thus, achieving the desired goals (Madanat and Ougeni, 2002). The evaluation of current education implicitly assumes a trust relationship between the teacher and the educational supervisor (Delandshere, 2002).

The first concern of educational supervision is improving the performance of teachers and striving to achieve everything that would facilitate their tasks, raise the level of the educational process, and provide whatever serves the work and achieve the desired goal. Since part of the responsibility for selecting, training, and developing the performance of teachers rests with supervision, educational supervision can improve educational outcomes by providing, improving, and evaluating appropriate experiences for teachers, and teaching conditions that aim at students' social and intellectual growth (Abu Gharbia, 2009).

The teacher's performance consists of carrying out the duties and tasks expected of him to accomplish. The teacher's duties and main tasks are to implement and prepare the educational process and to improve its 
effectiveness to achieve its goals. The main duties of the teacher include many things, the most important of which are: studying the educational objectives, identifying the levels of the students he teaches taking into account their differences, preparing the daily preparation notebook according to planning, implementing activities The various educational goals to achieve the goals, the evaluation of students to ensure the extent of achieving the goals, cooperation with the administration and the school staff for the sake of school work (Atwi, 2008).

With the changes and developments in the educational field, which affected all the elements of the educational system, the presence of a competent teacher is the cornerstone of the success of the educational process. The best books and curricula, educational aids, activities, and school buildings - despite their importance - do not achieve the desired educational goals, unless there is a teacher with educational competencies and distinct personal characteristics with which he can provide his students with various experiences, and complete the potential shortage in school books and curricula, and in its activities and potential. Teachers in general - and teachers of social studies in particular - cannot achieve the goals of the social studies curriculum efficiently and effectively without the presence of educational supervisors who can improve the performance of teachers, given that educational supervisors are described as leaders capable of developing the educational process. The educational supervisor is a central position in the educational system and its administration, as he represents a functional authority, as the supervisor derives his authority from the position, experience, and from the group to which the educational supervisor belongs (Al-Masad, 1986).

An educational supervisor is an important intermediate that can contribute effectively to the educational process through administrating activities that he performs and regulate the interactions of students among each other, and or with the teacher, or the supervisor himself. The role of educational supervision appears in the educational process by activating the performance of teachers, so that educational goals are achieved efficiently and effectively. As educational supervision constitutes a continuous evaluation process that aims to support the teacher by discussing positive and negative issues in his work, providing continuous guidance to raise the level of his experiences and skills, and working to increase his effectiveness (Al-Aklabi, 2001).

The success of the educational supervisor's work depends on successful planning and coordination of efforts, directing efforts toward achieving the desired goals, and that the position of educational supervisor distinguished in the educational system has earned him special importance due to his contact with the parties to the educational process. Therefore, the role 
of the educational supervisor must be appropriate to the needs of the parties to the educational process, and in line with what is expected of him, and this requires the educational supervisor to be reliable, and rely on the ethics of his profession such as honesty and integrity (Al-Khatib and Al-Khatib, 2003).

\section{Statement of the Problem:}

The problem of the current study is determined in an attempt to uncover the role of the educational supervisors in developing the professional performance of social studies teachers in Jordan from a teacher's perspective, particularly in Irbid Province. The researcher noticed this problem through direct contact with teachers of social studies and educational supervisors, and through discussions that took place in the meeting room inside the schools between the teachers themselves and the researcher, which helped the researcher to delve into some aspects of the problem and see some related studies. Through the researcher's review of several scientific studies and their results, the researcher noticed that there is a weakness in the performance of a large number of social studies teachers, and since educational supervision is an essential part of the educational process, and since educational supervisors have a responsibility and role in building the skills of social studies teachers, developing them and employing all their potentials, The researcher found an urgent necessity to try to uncover the truth about the role that educational supervisors play in developing the professional performance of social studies teachers.

\section{Research Questions:}

The study is determined to answer the following questions:

1. What is the role of the educational supervisors in developing the professional performance of social studies teachers in Jordan from a teacher's perspective in Irbid governorate schools in Jordan?

2. Are there statistically significant impact at the level of significance $(\alpha \leq 0.05)$ in teachers' opinions about the educational supervisor's role in developing the professional performance of social studies teachers attributed to the independent study variables (gender, academic qualification, school level, and years of experience)?

\section{Objectives of the Study:}

The main objective of the study is to identify the role of the educational supervisors in developing the professional performance of social studies teachers in Jordan from a teacher's perspective, by identifying the effect of (gender, academic qualification, school level, and years of experience) variables of social studies teachers on developing their professional 
performance by educational supervisors in Irbid governorate schools in Jordan.

\section{Importance of the Study:}

1. It may benefit the educational supervisors in general and the educational supervisors for social studies in particular to see the opinions of teachers towards them. Which will help him in the process of developing the educational process, and developing the performance of the teacher, based on the results of the study, by noting the aspects that the teacher needs to develop more than others, the role of the supervisor and his supervisory methods used to reach the desired development?

2. It may benefit decision-makers in the Jordanian Ministry of Education and the General Administration of Educational Supervision and Rehabilitation, to get acquainted with the reality of educational supervision in the city of Irbid, and to develop important programs and remedial plans in the aspect of educational supervision to develop teacher performance.

3. It may help teachers in the city of Irbid, by knowing the importance of the process of educational supervision and its relationship to the development of the educational learning process and the professional growth of the teacher, through the literature covered by this study in its theoretical background and previous studies, in addition to its results.

4. It may assist researchers in the field of educational supervision by informing them of the results and recommendations of the study and providing a research tool regarding the subject of educational supervision and its relationship to the enhancement of the performance of social education teachers.

\section{Study Limitations:}

Spatial boundary: government schools affiliated with the Jordanian Ministry of Education in Irbid Governorate in the Hashemite Kingdom of Jordan.

Human boundary: Social Studies teachers in government schools in the Directorate of Education in Irbid Governorate.

Time boundary: The study was conducted during the second semester of the academic year (2019-2020). 


\section{Procedural Terms of the Study:}

Role: A task or duty entrusted to a person in a specific job.

The current study defines the role that it is represented in the objectives that the supervisor must achieve from evaluating the teacher through various supervisory methods, giving feedback to the teacher, interaction between the supervisor and the teacher to improve the performance of the teacher and strengthen his strengths and reduce his weaknesses centered around the performance of the task or job.

Educational supervisor: is the person who holds the position of supervisor, and aims through his job to improve the educational and learning process and work to develop it from its various aspects, through interaction and communication processes (Al-Khatib and AlKhatib, 2003).

The current study defines the educational supervisor as a person who holds a degree in one of the specializations that qualify him to practice educational supervision as a profession, and his responsibilities include teacher development, curriculum improvement, educational facilities, and appointed as an educational supervisor by the Ministry of Education in the Directorate of Education in Irbid Governorate.

Performance development : It is intended to improve the tasks and duties performed by teachers within the educational process in terms of planning, teaching methods, evaluation, and community service. The degree of development reflects the responses of the study individuals to the paragraphs of the questionnaire.

Governmental schools in Irbid: Schools that are supervised by the Jordanian Ministry of Education in Irbid city and affiliated to the Irbid District.

\section{Theoretical Framework:}

Educational supervision is an integrative democratic process, and its means is communication with its various types, and its goal is to develop the educational-learning process through effective interaction between the educational supervisor, the teacher, and the student. Educational supervision in its general sense is a set of services and processes that are provided to help teachers to develop their teaching to provide students at all stages with a better level of educational services. To improve teachers' performance and develop their leadership skills in a way that does not achieve educational goals (Fitzgibbons, 2005). 
Among other definitions, educational supervision is: a group of studied activities carried out by specialized educators to help teachers develop themselves, and improve their educational and evaluation practices inside and outside the classroom, and to overcome all the difficulties that face them, to be able to implement the prescribed curricula and to achieve the educational goals set (Al-Asadi, 2003).

Through the previous presentation of the concept of educational supervision, the researcher believes that educational supervision is: efforts made to improve the educational learning process and develop it by helping teachers develop their leadership skills, improve their abilities, solve their problems, and overcome obstacles that encounter them, as the specialists are interested in supervising the educational learning situation With all its elements, including curricula, means, methods, environment, teacher, student, and administration, in a way that leads to raising the level of teachers' capabilities in a way that achieves educational and educational goals. Perhaps the most important thing that can be observed from the previous definitions is that it is characterized by the fact that it emphasizes to a large extent one aspect of the educational process, such as administration, curricula, teaching, or human relations, as it is one-way (Giannola, 2005).

\section{Objectives of Educational Supervision:}

The educational supervision process has become organized, aiming at the advancement of the human being who by nature needs help and cooperation with others, improving the teaching and learning processes, the quality of the educational and educational process, and upgrading the factors affecting it. Accordingly, the objectives of educational supervision can be summarized with the following goals: Work on developing the curriculum in its three dimensions (content, style, and evaluation) by studying and analyzing educational curricula, linking the academic material students learn, modifying teaching methods to suit the groups of students, and taking into account individual differences between them, and assisting teachers in planning, preparing tools and tests and analyzing their results, to ensure the achievement of social and educational goals, as well as, helping them to identify the best educational methods and use them in teaching their subjects and inform them of everything new in the field of their specialization (Al-Badri, 2008).

The educational supervision process aims to achieve cooperation and coordination with the relevant competent authorities in planning and implementing education and training programs, books, curricula, and teaching methods, and to activate participation in training workers in the field on selfevaluation and evaluation of others. As well as, achieving teachers' understanding of the role that educational supervision plays as a component of the educational and learning process, and monitoring the necessary needs 
in a way that contributes to making decisions in the amendment and development for the better (Hassan, 2003).

The importance of educational supervision also stems from its importance in revealing the needs of teachers, forming human relations between the teaching staff so that their morale rises and working to achieve the goals of the school, as well as, working on laying the foundations for respecting the teacher's personality and respect for his special abilities, or helping him to become able to direct and identifies his problems and analyzes them, and provides assistance to teachers to benefit from the local environment, and to identify its material and human resources such as historical places, industrial centers, museums, and others (Al-Badri, 2008).

\section{Professional Competencies of the Educational Supervisor:}

For the educational supervisor to achieve specific educational goals, and for him to fulfill all his tasks and duties to the fullest, the supervisor must have some important characteristics for the success of his work. The educational supervisor is supposed to seek to complete his supervisory competencies by various means of growth, such as academic study continuous self-study, participation in training and development courses continuously, and work to exchange knowledge and experiences with colleagues at work, and the various competencies that must be available in the educational supervisor and the most important of these competencies are personal competence, by building his personality to be a good example for teachers, and his enjoyment with integrity, fairness, modesty, tact, intelligence, commitment to professional ethics and self-confidence (Ferguson, 2004).

An educational supervisor is also supposed to have a set of performance competencies through developing his ability to design and prepare a flexible and renewable annual supervisory plan, the ability to plan, the ability to lead and evaluate training courses, in addition to having a set of scientific competencies, including deep knowledge of his subject matter, and broad culture And diverse, as well as possessing some social competencies such as the ability to establish good and human relations with members of the educational community (Al-Badri, 2008).

Competencies that the educational supervisor should have been classified into knowledge and remembering, comprehension competencies, performance competencies, and product competencies, given that the competence includes four aspects: the cognitive absorptive, the performance related to the results of the training, and the productive and emotional. For the educational supervisor to be able to carry out his various roles effectively and efficiently, he must have a set of special skills or competencies that are distinguished by originality, contemporary, connection with society, and 
keeping pace with his development to achieve the desired educational goals (Justice, 2007).

\section{Areas of Work of Educational Supervision:}

The educational supervisor's work has varied work in cooperation with all elements of the school community to improve the educational learning process outcomes, and the educational supervisor plans for his work in balanced and accurate planning, setting clear and measurable goals, modern and influential means, methods, activities, and evaluation tools that extend and expand to include all areas of the educational process (Obeidat and Abu AlSameed, 2007).

Among the most important of these areas are the following:

- Planning: Scientific planning that is characterized by innovation and innovation is one of the most prominent areas of the educational supervisor's work because all other areas are related to it and are based on it.

- The student is the goal of the educational process and the most important element in the educational system. As all activities in all areas are geared to serve him cognitively, skillfully, and emotionally; to achieve the integrated growth for him, and to give him good values and habits, and thus bring about the desired change in his behavior and ways of thinking (Al-Badri, 2008).

- The teacher: If the student is the focus of the educational process, then the teacher is its driver and leader, and noble goals cannot be achieved without him, and the educational supervisor's interest in the teacher is based on his interest in the student, and the teacher is a social reformer and a great leader of the nation's civilization march, so the advanced nations gave him their attention. And worked to fulfill his requirements (Alarcao, 2009).

- The school curriculum: The curriculum was found in the existence of the school, and it grew in response to the developments that have occurred in its social function, and it is not just theoretical subjects, but rather it is the nation's thought, belief, history, heritage, and the variables of civilization in it, and it extends to other nations, cultures, religions, and aspects of social activity. (Homana, 2007).

- Teaching methods: The proper and conscious choice of teaching methods requires a special skill that teachers should be trained on to take into account the individual differences between students, and to suit their temporal and mental ages, educational levels, and stages of their development. A successful teacher is the one who chooses the appropriate method that helps him to achieve his goals. The 
educational supervisor should encourage teachers to adopt appropriate methods of teaching (Ayesh, 2008).

- Activities: School activities are no less important than the subject, and they are complementary to it, because it meets the needs of students, raise their interests, and helps to bring about the desired changes in their behavior and their ways of thinking. And education in the Arab world to include activities in the school plan, like all other subjects, and it has become practiced under the supervision of teachers and educational supervisors inside and outside the school, and the educational supervisor follows up the activities related to his topic, and works to develop and enhance them, and improve opportunities for benefiting from them.

- Teaching aids: Teaching aids are one of the basic inputs to the educational learning process, which is useful in raising the level of students by improving the quality of education by preparing creative interaction between the teacher and his students to achieve the planned behavioral goals, and the educational supervisor cooperates with teachers in selecting and providing modern technologies to serve Teaching Strategy and Techniques (Hussein and Abu Al-Wafa, 2008).

- School buildings: They are the places in which the educational and learning process is practiced, and in which classroom interaction takes place, and the conscious educational departments are keen to provide school buildings that help implement the various educational interaction activities in terms of their calmness, breadth, and integration of their facilities. Educational supervision has a role in preserving the safety of the school building so that it remains suitable for achieving the purposes for which it was built.

- Measurement and evaluation: it is concerned with educational supervision with measuring and evaluation tools and it cooperates with teachers in highlighting their importance and clarifying their types and methods of construction (Al-Ajami, 2008).

\section{Methods of Educational Supervision:}

There are varied methods of educational supervision, and the most important of these supervisory methods are the following:

Classroom visit, and is considered one of the oldest methods of educational supervision and it depends on the educational supervisor visiting the school and getting acquainted with the reality of the educational process in the school itself, and inside the classroom. Knowing the reality of the teacher, the student, the curriculum, and the educational climate in the school, and after the supervisor visits the school, he discusses the information that he wrote with the teacher in an attempt to guide him and improve his performance 
in the classroom, and among the types of classroom visits: the surprise visit, the agreed visit, and the required visit which is on Building the teacher's request (Abdul Hadi, 2002).

There is also the individual interview, which is based on a minimeeting between the supervisor and the teacher, whether before or after the class visit and during the interview the supervisor provides his observations on a specific situation or proposes a solution or treatment for a problem or aspect of weakness that the teacher may suffer from The importance of this method is that it allows the building of a kind of trust between the supervisor and the teacher. Among other methods in the field of educational supervision is the method of exchange supervision: It is another means of supervision, which the educational supervisor plans in coordination with teachers to enable them to visit their more qualified and long-experienced colleagues, so the teacher or several teachers visit another teacher, and micro-education is also used in the face of Special for training teachers before service and during service in a simplified framework, as it takes a short time and uses a small number of students. Among its advantages is actual, real education, and it facilitates the complex factors that enter the educational situation and allows for immediate feedback on a specific point or points. It is used in preparing teachers before service and during service, in preparing university professors, and in preparing educational counselors (Al-Badri, 2008).

\section{Relationship Between Educational Supervisor And Teachers:}

The process of improving and upgrading the educational process is a vision that everyone seeks to achieve its goals, to advance students' achievement through the professional development of teachers and develop their performance, which is the most important motivation in improving the level of students, activating the relationship of workers in the field of education and creating convictions in the importance of cooperation and participatory work and exchange experiences and knowledge between them and train and qualify them, especially new teachers.

The supervisor is a guide and instructor, and he must in this regard not condone teachers or extend his control over them, and his relationship with them must be that of colleagues in the profession, and their participation in the duties and tasks assigned to them to develop the educational and educational process, and he deals objectively with teachers and gives everyone his right. The educational supervisor must work to continuously develop his competencies and not think that he has reached a stage of perfection after which he does not need progress and development, but rather he must always deal with ingenuity and dexterity. Also, among the features of a successful and effective supervisor: enjoying high morale among teachers and working to provide a sense of security, and not undermining confidence in themselves and 
their professional ability. He must also work continuously to strengthen the bonds of professional and social relations between workers in the teaching profession and to promote these ties and elevate them (Fenish and Zidan, 2000).

The supervisor must also work on using the simplest and easiest means, and make it accessible and affordable for the teacher, and for students to achieve the desired educational goals, and he must also be keen on progressive progress in work (Al-Khatib et al., 2002).

Al-Maghidi (2001) emphasized that the principles that bind the educational supervisor to the teachers are represented like the relationship that governs every democratic leader with whom they work, and perhaps these principles are centered around the educational supervisor's appreciation of the effort exerted by the teacher, protecting the teacher, raising his morale and satisfying his basic needs. His contact with the teacher is characterized by clarity, accuracy, objectivity, and a deep mutual understanding, in addition to his continuous endeavor to strengthen the bonds of professional and social relations between him and teachers on the one hand and between teachers themselves on the other hand, and to work to achieve equal opportunities among teachers and develop their abilities in employing and using educational means and technologies. Modern teaching strategies, in addition to encouraging teachers to conduct scientific research to study educational problems and phenomena.

The relationship between the educational supervisor and the teacher aims at upgrading the teacher's skills, to reach the model teacher in the educational and educational process, as he is a mentor, facilitator, guide, and evaluator, he should possess a set of skills, characteristics and competencies that distinguish him from others and prepare him for the ability to fulfill the duties and tasks assigned to him To the fullest, through planning the educational-learning process, implementing its various procedures and activities, the ability to effectively manage the classroom, and finally, conducting continuous evaluation processes in light of the desired goals, and with these components and elements the teaching performance is represented, and as far as the teacher's efficiency in it is reflected positively on his performance (Al-Khatib, et al., 2002).

\section{Previous Studies:}

The study of Sharia (2019), aimed to identify the role of educational supervision in improving the performance of teachers from the point of view of the teachers in the Directorate of Education of Altaybah and Alwasteyah of Irbid governorate. The descriptive method was used and an electronic questionnaire was distributed randomly to a sample of 200 male and female teachers. The study concluded that there were statistically significant 
differences attributed to gender in teaching and evaluation strategies for female teachers, while there were no statistically significant differences in the field of planning and the tool as a whole. The study variable (teaching, planning, and evaluation) were intermediate status.

The study of Al-Hamdoun (2016), aimed to identify the role of physical education supervisors in developing school sports for education directorates from the point of view of teachers in the Mafraq governorate. The researcher used the descriptive survey approach through a questionnaire distributed to a sample of teachers in Mafraq Governorate. The researcher has reached several results, the most important of which is that the role of physical education supervisors in developing school sports in the field of planning was at a high level, while in the fields of teaching, professional growth, and incentives, it was of a moderate degree, and there were no statistically significant differences for the study variables for educational qualifications, gender, experience, and directorate.

The study of Hamida (2012), aimed to identify the role of the educational supervisor in improving the performance of kindergarten teachers in developing children's language skills from the viewpoint of kindergarten teachers in Jordan. The study sample consisted of (312) kindergarten teachers from special education directorates in the governorates of Amman, Mafraq, and Irbid. A questionnaire was constructed consisting of (63) items distributed into five domains, the results of the study showed that the degree of the educational supervisor's role in improving the performance of kindergarten teachers was low in most areas and all areas combined. The results also showed that there are no statistically significant differences between the opinion of the educational supervisor's role in improving the performance of kindergarten teachers in developing children's language skills from the teachers' point of view in the educational supervisor's role, attributable to academic qualification, years of experience, and location, and teachers' performance in developing children's language skills.

The study of Tim (2009), aimed to identify the reality of the supervisory practices of the educational supervisor in the governorates of northern Palestine from the point of view of male and female teachers. The study sample consisted of (391) male and female teachers, distributed in four governorates (Nablus, Tulkarm, Qalqilya, Jenin) A questionnaire was designed that covered supervisory practices and the results of the study indicated in general that the reality of supervisory practices of the educational supervisor in public schools in the northern governorates of Palestine was weak and that the reality of supervisory practices varies according to educational qualification, educational stage, and place of residence.

The study of Al-Shaddadi (2009), aimed to identify the role of the educational supervisor in improving the educational performance of teachers 
with learning difficulties from the teachers' point of view. The study used the descriptive approach and the questionnaire to collect information. The study sample consisted of (55) teachers, and the study concluded that the degree of the supervisor's role in improving the educational performance of teachers with learning difficulties was high on all study axes, and there were no statistically significant differences between the averages of the responses of the study population; Because of the difference in the educational experience.

The study of Al-Dossary (2008), aimed to know the role of the educational supervisor in raising the efficiency of the job performance of art education teachers, and the study sample consisted of (54) teachers, and the study used the questionnaire as a tool to collect information that serves the objectives of the study, and the results showed that there are deficiencies of some supervisors in directing education teachers Technical to separate each classroom separately in the preparation book, and the use of educational aids, and interest in continuous evaluation, and the lack of interest of officials in the report of the educational supervisor.

The study of Siam (2007), also aimed to identify the role of educational supervision methods in developing the professional performance of teachers in secondary schools in Gaza Governorate. The researcher used the descriptive and analytical approach, and the questionnaire was applied to the study sample consisting of (226) male and female teachers working in secondary schools. In Gaza governorate, the study found that teachers 'practice of educational planning skills, lesson implementation skills, classroom management skills, and assessment skills are moderate and that there are statistically significant differences in the expected estimates of the role of supervision methods in developing teachers' professional performance, due to the variable of gender, academic qualification, and specialization. In the field of planning and implementation of teaching and evaluation, while there are statistically significant differences due to years of service in the field of classroom management.

The study of Al-Hajri (2007), aimed at identifying the role of educational supervisors in developing the performance of Islamic education teachers in the State of Kuwait from the teachers 'point of view. The researcher selected the study sample using the stratified random method at a rate of $(15 \%)$ from the original community, whose number is (1363) male and female teachers. Thus, the number of the study sample reached 198 male and female teachers, and a questionnaire was prepared to consist of (29) items distributed into five Areas of which are: (planning, curriculum development, and teaching methods, teacher professional development, human relations, evaluation, and examinations). The results of the study showed that the role of educational supervisors in developing the performance of Islamic education 
teachers in the State of Kuwait from the teachers 'point of view was to a large extent.

The study of Qazak (2006), aimed at determining the role of the educational supervisor in improving the professional development of teachers of the first three grades in the governorate of Irbid, and aimed at identifying the extent of the educational supervisor's practice of his role in improving the professional development of teachers of previous grades according to the gender, experience, and qualification of the teacher and the supervisor. To achieve the aim of the study, a questionnaire was designed consisting of (59) items, and it was divided into (6) areas, namely: planning, classroom interaction, classroom management, keeping order, study methods, professional, academic growth, and evaluation, which was distributed among a sample consisting of (236) supervisors, male and female teachers, including (17) supervisors, and (219) teachers, were chosen randomly. Statistically significant differences were found in all fields of study, and the overall tool was due to the job variable, in favor of supervisors, study methods, professional and academic growth.

The study of Ferguson (2004), aimed to explain the role of educational supervision in improving the performance of teachers, the types of supervisory methods chosen by the supervisor to improve the performance of teachers and to know the difficulties facing mathematics teachers, and the study sample consisted of (300) teachers, and (53) a supervisor, and the questionnaire was used as a tool for the study, and among the most important results was that the role of educational supervision is necessary to improve the performance of mathematics teachers and that the application of different supervision methods helps to improve the professional performance of teachers.

The study of Khawaldeh (2002), aimed to clarify the role of the supervisor of Islamic education in improving the performance of subject teachers in the University Brigade Schools of the Amman Second District, which numbered (65) teachers. The role of educational supervisors in improving the performance of Islamic education teachers is of a medium degree. The results also showed that there were statistically significant differences at the level of significance $(\alpha=0.05)$ for the role of the Islamic Education Supervisor in improving the performance of subject teachers from the teachers' viewpoint due to the variables of gender, academic qualification, and experience.

\section{Materials and Methods of the Study: \\ Research Methodology:}

The descriptive and analytical approachs were used to answering the study's questions. The study population consisted of all the (690) teachers of social studies in primary and secondary schools in the directorates of 
education in the governorate of Irbid of Jordan, according to the academic year 2019/2020 statistics. The study sample included (120) male and female teachers (60 male and 60 female) selected randomly as shown in table (1).

A researcher-made questionnaire was designed consisted of two sections, the first section included questions related to the demographical characteristics of the respondents (Gender, Academic Qualifications, School Level, and Years of Experience), while the second section included (35) questions of 5-point Liker-type Scale divided into five sub-sections (Planning, Teaching Methods, classroom visits, relationship with colleagues and the local community, and Evaluation) each sub-section contained (7) questions. Finally, the Statistical Packages for Social Sciences (SPSS) software was used to analyze the data of the study. To explain the responses of the study members, the following pentagonal ranking was adopted: 1.00- 2.33 (Low), 2.34-3.67 (Moderate), and 3.68-5 (High).

Table (1) Distribution of research sample according to the demographic variables

\begin{tabular}{|c|c|c|c|}
\hline \multicolumn{2}{|c|}{ Variables } & Frequency & Percentage \\
\hline \multirow{3}{*}{ Gender } & Male & 60 & $50 \%$ \\
\hline & Female & 60 & $50 \%$ \\
\hline & Total & 120 & $100 \%$ \\
\hline \multirow{3}{*}{$\begin{array}{c}\text { Academic } \\
\text { Qualifications }\end{array}$} & Undergraduate & 114 & $95 \%$ \\
\hline & Postgraduate & 6 & $5 \%$ \\
\hline & Total & 120 & $100 \%$ \\
\hline \multirow{3}{*}{ School Level } & Primary & 86 & $72 \%$ \\
\hline & Secondary & 34 & $28 \%$ \\
\hline & Total & 120 & $100 \%$ \\
\hline \multirow{3}{*}{$\begin{array}{c}\text { Years of } \\
\text { Experience }\end{array}$} & $\begin{array}{c}10 \text { years and } \\
\text { less }\end{array}$ & 93 & $77.5 \%$ \\
\hline & $\begin{array}{c}\text { More than } 10 \\
\text { years }\end{array}$ & 27 & $22.5 \%$ \\
\hline & Total & 120 & $100 \%$ \\
\hline
\end{tabular}

\section{Validity and Stability of the Instrument}

Face validity of the questionnaire was confirmed by a group of 6 field experts, corrections were made then to produce the questionnaire in its final form. To estimate the stability of the questionnaire, the value of the Cronbach alpha Test was calculated on a survey of 11 paragraphs and the stability coefficient was 0.91 which is considered acceptable to conduct the study as shown in table (2).

\begin{tabular}{|c|c|}
\hline \multicolumn{2}{|c|}{ Table (2) } \\
Reliability Statistics \\
\hline Cronbach's Alpha & N of Items \\
\hline 0.91 & 11 \\
\hline
\end{tabular}

As well, The Pearson correlation coefficient test between independent variables was measured as in table (3). 
Table (3) Correlation Coefficient Test between the independent variables

\begin{tabular}{|c|c|c|c|c|c|}
\hline Variables & Planning & $\begin{array}{c}\text { Teaching } \\
\text { Methods }\end{array}$ & $\begin{array}{c}\text { Relationship } \\
\text { with colleagues } \\
\text { and local } \\
\text { community }\end{array}$ & $\begin{array}{c}\text { Classroom } \\
\text { visits }\end{array}$ & Evaluation \\
\hline Planning & 1 & 0.26 & 0.07 & 0.43 & 0.52 \\
\hline $\begin{array}{c}\text { Teaching } \\
\text { Methods }\end{array}$ & 0.26 & 1 & 0.61 & 0.16 & 0.22 \\
\hline $\begin{array}{c}\text { Relationship } \\
\text { with colleagues } \\
\text { and local } \\
\text { community }\end{array}$ & 0.07 & 0.61 & 1 & 0.27 & 0.80 \\
\hline $\begin{array}{c}\text { Classroom } \\
\text { visits }\end{array}$ & 0.43 & 0.16 & 0.27 & 1 & 0.43 \\
\hline Evaluation & 0.52 & 0.22 & 0.80 & 0.43 & 1 \\
\hline
\end{tabular}

Table (3) shows the correlation coefficient between the independent variables under study, as it appears that, there is no high correlation between the independent variables.

\section{Discussion of Results:}

First Question: What is the role of the educational supervisors in developing the professional performance of social studies teachers in Jordan from a teacher's perspective in Irbid governorate schools in Jordan?

To answer this question, arithmetic means and standard deviations of the role of educational supervisors in developing the professional performance of social studies teachers in Irbid governorate were calculated on the fields of the study variables, and on the tool as a whole as follow:

\section{Planning Field: .I}

Table (4) Arithmetic Mean And Standard Deviations Of The Role Of Educational Supervisors In Developing The Professional Performance Of Social Studies Teachers In The Field Of Planning Arranged In Descending Order

\begin{tabular}{|c|c|l|c|c|c|}
\hline Rank & $\begin{array}{l}\text { Paragraph } \\
\text { Number }\end{array}$ & Paragraph & $\begin{array}{l}\text { Arithmetic } \\
\text { Mean }\end{array}$ & $\begin{array}{l}\text { Standard } \\
\text { Deviation }\end{array}$ & Status \\
\hline 1 & 2 & $\begin{array}{l}\text { The educational } \\
\text { supervisor evaluates } \\
\text { the educational } \\
\text { plans related to the } \\
\text { social studies } \\
\text { teacher }\end{array}$ & 4.27 & 0.82 & High \\
\hline 2 & 6 & $\begin{array}{l}\text { The educational } \\
\text { supervisor monitors } \\
\text { the achievement of }\end{array}$ & 4.22 & 0.91 & High \\
\hline
\end{tabular}




\begin{tabular}{|c|c|c|c|c|c|}
\hline & & $\begin{array}{l}\text { the goals of the } \\
\text { plans set by the } \\
\text { social studies } \\
\text { teacher }\end{array}$ & & & \\
\hline 3 & 5 & $\begin{array}{l}\text { The supervisor } \\
\text { focuses on the } \\
\text { teacher's } \\
\text { consideration of } \\
\text { time in the planning } \\
\text { process }\end{array}$ & 4.01 & 1.17 & High \\
\hline 4 & 4 & $\begin{array}{l}\text { The educational } \\
\text { supervisor directs } \\
\text { the teacher to set a } \\
\text { schedule for } \\
\text { implementing the } \\
\text { subject units }\end{array}$ & 3.78 & 2.24 & High \\
\hline 5 & 7 & $\begin{array}{l}\text { The educational } \\
\text { supervisor discusses } \\
\text { the social studies } \\
\text { teacher, plans to } \\
\text { raise the level of } \\
\text { student achievement }\end{array}$ & 3.64 & 0.73 & Moderate \\
\hline 6 & 3 & $\begin{array}{l}\text { The educational } \\
\text { supervisor trains the } \\
\text { teacher to develop } \\
\text { appropriate plans } \\
\text { for those with low } \\
\text { achievement }\end{array}$ & 3.17 & 0.91 & Moderate \\
\hline 7 & 1 & $\begin{array}{l}\text { The educational } \\
\text { supervisor } \\
\text { participates with the } \\
\text { social studies } \\
\text { teacher in drawing } \\
\text { up the daily and } \\
\text { annual school plans }\end{array}$ & 2.14 & 1.13 & Low \\
\hline \multicolumn{3}{|c|}{ The Field as a whole } & 3.60 & 1.13 & Moderate \\
\hline
\end{tabular}

Table (4) shows that the arithmetical mean of the field of planning range from (2.14 -4.27), where the paragraph of "The educational supervisor evaluates the educational plans related to the social studies teacher" came first with an Arithmetic Mean of (4.27) and a Standard Deviation of (0.82), while the paragraph of " The educational supervisor participates with the social studies teacher in drawing up the daily and annual school plans" came last with an Arithmetic Mean of (2.14) with a Standard Deviation of (1.13). The Arithmetic Mean of the field of planning as a whole amounted to (3.60) with a Standard Deviation of (1.13) that has a moderate status. 


\section{Teaching Methods Field:}

Table (5)Arithmetic Mean And Standard Deviations Of The Role Of Educational Supervisors In Developing The Professional Performance Of Social Studies Teachers On

The Field Of Teaching Methods Arranged In Descending Order

\begin{tabular}{|c|c|c|c|c|c|}
\hline Rank & $\begin{array}{c}\text { Paragraph } \\
\text { Number }\end{array}$ & Paragraph & $\begin{array}{c}\text { Arithmetic } \\
\text { Mean }\end{array}$ & $\begin{array}{l}\text { Standard } \\
\text { Deviation }\end{array}$ & Status \\
\hline 1 & 10 & $\begin{array}{l}\text { The educational } \\
\text { supervisor follows } \\
\text { up the curriculum } \\
\text { implementation } \\
\text { plan with the } \\
\text { teachers }\end{array}$ & 3.97 & 1.23 & High \\
\hline 2 & 13 & $\begin{array}{l}\text { The educational } \\
\text { supervisor directs } \\
\text { the teacher to use } \\
\text { sources other than } \\
\text { the textbook }\end{array}$ & 3.77 & 0.88 & High \\
\hline 3 & 11 & $\begin{array}{l}\text { The educational } \\
\text { supervisor explains } \\
\text { to the teacher some } \\
\text { of the terms and } \\
\text { concepts mentioned } \\
\text { in the textbook }\end{array}$ & 3.52 & 0.73 & Moderate \\
\hline 4 & 8 & $\begin{array}{l}\text { The educational } \\
\text { supervisor discusses } \\
\text { with the teacher the } \\
\text { goals of the } \\
\text { curriculum }\end{array}$ & 3.07 & 1.63 & Moderate \\
\hline 5 & 12 & $\begin{array}{l}\text { The educational } \\
\text { supervisor directs } \\
\text { the teacher on how } \\
\text { to use the teacher's } \\
\text { guide }\end{array}$ & 2.14 & 2.17 & Low \\
\hline 6 & 14 & $\begin{array}{l}\text { The educational } \\
\text { supervisor trains the } \\
\text { teacher on the } \\
\text { various } \\
\text { communication } \\
\text { means }\end{array}$ & 1.77 & 0.86 & Low \\
\hline 7 & 9 & $\begin{array}{l}\text { The educational } \\
\text { supervisor involves } \\
\text { the teacher in } \\
\text { evaluating the } \\
\text { school curriculum }\end{array}$ & 1.53 & 1.12 & Low \\
\hline \multicolumn{3}{|c|}{ The Field as a whole } & 2.82 & 1.23 & Moderate \\
\hline
\end{tabular}

Table (5) shows that the Arithmetical Mean of the field of teaching methods range from (1.53-3.97), where the paragraph of "The educational supervisor follows up the curriculum implementation plan with the teachers" 
came first with an Arithmetical Mean of (3.97) and a Standard Deviation of (1.23), while the paragraph of "The educational supervisor involves the teacher in evaluating the school curriculum" came last with an Arithmetical Mean of (1.53) with a Standard Deviation of (1.12), the Arithmetical Mean of the field of planning as a whole amounted at (2.82) with a Standard Deviation of (1.23), that has a moderate status.

\section{Relationship With Colleagues And Local Community Field:}

Table (6)Arithmetic Mean And Standard Deviations Of The Role Of Educational Supervisors In Developing The Professional Performance Of Social Studies' Teachers In The Field Of Relationship With Colleagues And Local Community Arranged In Descending

\begin{tabular}{|c|c|c|c|c|c|}
\hline Rank & $\begin{array}{c}\text { Paragraph } \\
\text { Number }\end{array}$ & Paragraph & $\begin{array}{c}\text { Arithmetic } \\
\text { Mean }\end{array}$ & $\begin{array}{l}\text { Standard } \\
\text { Deviation } \\
\end{array}$ & Status \\
\hline 1 & 16 & $\begin{array}{l}\text { The educational } \\
\text { supervisor runs a } \\
\text { periodic visits } \\
\text { program for social } \\
\text { studies teachers }\end{array}$ & 4.72 & 1.63 & High \\
\hline 2 & 20 & $\begin{array}{l}\text { The educational } \\
\text { supervisor } \\
\text { encourages the } \\
\text { social studies } \\
\text { teacher to take into } \\
\text { account the learners' } \\
\text { personal and } \\
\text { educational needs }\end{array}$ & 4.64 & 0.94 & High \\
\hline 3 & 19 & $\begin{array}{l}\text { The educational } \\
\text { supervisor guides } \\
\text { the social studies } \\
\text { teacher to what he } \\
\text { sees as deficiencies }\end{array}$ & 4.12 & 1.22 & High \\
\hline 4 & 15 & $\begin{array}{l}\text { The educational } \\
\text { supervisor } \\
\text { maintains good } \\
\text { human relations } \\
\text { with teachers of } \\
\text { social studies } \\
\end{array}$ & 4.10 & 0.76 & High \\
\hline 5 & 17 & $\begin{array}{l}\text { The educational } \\
\text { supervisor makes } \\
\text { surprise visits to the } \\
\text { teacher from time to } \\
\text { time }\end{array}$ & 3.97 & 0.83 & High \\
\hline 6 & 21 & $\begin{array}{l}\text { The educational } \\
\text { supervisor accepts } \\
\text { the opinions and } \\
\text { observations of the }\end{array}$ & 3.85 & 1.64 & High \\
\hline
\end{tabular}




\begin{tabular}{|c|c|l|l|l|l|}
\hline & & $\begin{array}{l}\text { social studies } \\
\text { teachers }\end{array}$ & & \\
\hline 7 & $\begin{array}{l}\text { The educational } \\
\text { supervisor provides } \\
\text { the social studies } \\
\text { teacher with all that } \\
\text { is new in social } \\
\text { studies }\end{array}$ & 2.63 & 1.86 & Moderate \\
\hline \multicolumn{2}{|l|}{ The Field as a whole } & $\mathbf{4 . 0 0}$ & $\mathbf{1 . 2 7}$ & High \\
\hline
\end{tabular}

Table (6) shows that the Arithmetical Mean of the field of Relationship with colleagues and the local community range from (2.63-4.72), where the paragraph of "The educational supervisor runs a periodic visits program for social studies teachers" came first with an Arithmetical Mean of (3.97) and a Standard Deviation of (1.23), while the paragraph of "The educational supervisor provides the social studies teacher with all that is new in social studies" came last with an Arithmetical Mean of (1.63) with a Standard Deviation of (1.86), the Arithmetical Mean of the field of planning as a whole amounted at (4.00) with a Standard Deviation of (1.27), that has a high status.

\section{Classroom Visits Field:}

Table (7) Arithmetic Mean and Standard Deviations of the Role of Educational Supervisors in Developing the Professional Performance of Social Studies Teachers in the Field Of

Classroom Visits

\begin{tabular}{|c|c|l|c|c|c|}
\hline Rank & $\begin{array}{l}\text { Paragraph } \\
\text { Number }\end{array}$ & Paragraph & $\begin{array}{l}\text { Arithmetic } \\
\text { Mean }\end{array}$ & $\begin{array}{l}\text { Standard } \\
\text { Deviation }\end{array}$ & Status \\
\hline 1 & 22 & $\begin{array}{l}\text { The educational } \\
\text { supervisor informs } \\
\text { the social studies } \\
\text { teacher of the } \\
\text { content of the } \\
\text { classroom visit }\end{array}$ & 4.92 & 0.71 & High \\
\hline 2 & 28 & $\begin{array}{l}\text { The educational } \\
\text { supervisor looks at } \\
\text { the semester plan } \\
\text { prepared by the } \\
\text { teacher }\end{array}$ & 4.90 & 0.83 & High \\
\hline 3 & 27 & $\begin{array}{l}\text { The educational } \\
\text { supervisor praises } \\
\text { the teacher upon } \\
\text { leaving the } \\
\text { classroom }\end{array}$ & 4.87 & 0.91 & High \\
\hline 4 & 23 & $\begin{array}{l}\text { The educational } \\
\text { supervisor deals } \\
\text { with the social } \\
\text { studies teacher in a } \\
\text { framework of }\end{array}$ & 4.37 & 1.02 & High \\
\hline
\end{tabular}




\begin{tabular}{|c|c|c|c|c|c|}
\hline & & $\begin{array}{l}\text { cooperation and } \\
\text { mutual respect }\end{array}$ & & & \\
\hline 5 & 26 & $\begin{array}{l}\text { The educational } \\
\text { supervisor provides } \\
\text { an atmosphere of } \\
\text { familiarity with the } \\
\text { teacher before } \\
\text { attending the class }\end{array}$ & 4.22 & 0.97 & High \\
\hline 6 & 25 & $\begin{array}{l}\text { The educational } \\
\text { supervisor } \\
\text { encourages the } \\
\text { teacher to exchange } \\
\text { visits between } \\
\text { social studies } \\
\text { teachers in the } \\
\text { different schools }\end{array}$ & 3.82 & 0.63 & High \\
\hline 7 & 24 & $\begin{array}{l}\text { The educational } \\
\text { supervisor directs } \\
\text { letters of thanks to } \\
\text { the distinguished } \\
\text { social studies } \\
\text { teachers }\end{array}$ & 1.65 & 1.33 & Low \\
\hline \multicolumn{3}{|c|}{ The Field as a whole } & 4.11 & 0.91 & High \\
\hline
\end{tabular}

Table (7) shows that the Arithmetical Mean of the field of Relationship with colleagues and local community range from (1.65-4.92), where the paragraph of "The educational supervisor informs the social studies teacher of the content of the classroom visit " came first with an Arithmetical Mean of (4.92) and a Standard Deviation of (0.71), while the paragraph of "The educational supervisor directs letters of thanks to the distinguished social studies' teachers" came last with an Arithmetical Mean of (1.65) with a Standard Deviation of (1.33), the Arithmetical Mean of the field of planning as a whole amounted at (4.11) with a Standard Deviation of (0.91), that has a high status. 


\section{Evaluation Field:}

Table (8) Arithmetic Mean and Standard Deviations of the Role of Educational Supervisors in Developinging the Professional Performance of Social Studies' Teachers in the Field Of

Evaluation Arranged In Descending Order

\begin{tabular}{|c|c|c|c|c|c|}
\hline Rank & $\begin{array}{c}\text { Paragraph } \\
\text { Number }\end{array}$ & Paragraph & $\begin{array}{l}\text { Arithmetic } \\
\text { Mean }\end{array}$ & $\begin{array}{l}\text { Standard } \\
\text { Deviation }\end{array}$ & Status \\
\hline 1 & 30 & $\begin{array}{l}\text { The educational } \\
\text { supervisor shall } \\
\text { keep his opinions } \\
\text { and evaluation } \\
\text { judgments } \\
\text { completely } \\
\text { confidential }\end{array}$ & 4.12 & 0.83 & High \\
\hline 2 & 32 & $\begin{array}{l}\text { The educational } \\
\text { supervisor informs } \\
\text { the teacher of the } \\
\text { positive and } \\
\text { negative aspects of } \\
\text { his performance }\end{array}$ & 4.07 & 0.94 & High \\
\hline 3 & 31 & $\begin{array}{l}\text { The educational } \\
\text { supervisor trains } \\
\text { teachers to conduct } \\
\text { various tests such as } \\
\text { (achievement, } \\
\text { diagnosis ...) }\end{array}$ & 3.06 & 1.26 & Moderate \\
\hline 4 & 35 & $\begin{array}{l}\text { The educational } \\
\text { supervisor explains } \\
\text { to the teacher the } \\
\text { importance of } \\
\text { reinforcement and } \\
\text { feedback for } \\
\text { students }\end{array}$ & 2.92 & 1.17 & Moderate \\
\hline 5 & 34 & $\begin{array}{l}\text { The educational } \\
\text { supervisor urges } \\
\text { teachers of social } \\
\text { studies to } \\
\text { investigate accuracy } \\
\text { and objectivity in } \\
\text { evaluating learners' } \\
\text { performance }\end{array}$ & 2.64 & 0.76 & Moderate \\
\hline 6 & 29 & $\begin{array}{l}\text { The educational } \\
\text { supervisor applies } \\
\text { modern methods of } \\
\text { evaluating teachers }\end{array}$ & 2.18 & 1.53 & Low \\
\hline 7 & 33 & $\begin{array}{l}\text { The educational } \\
\text { supervisor follows } \\
\text { up on the evaluation } \\
\text { results for social } \\
\text { studies teachers }\end{array}$ & 1.83 & 0.67 & Low \\
\hline \multicolumn{3}{|c|}{ The Field as a whole } & 2.97 & 1.02 & Moderate \\
\hline
\end{tabular}


Table (8) shows that the Arithmetical Mean of the field of Relationship with colleagues and the local community range from (1.83-4.12), where the paragraph of "The educational supervisor shall keep his opinions and evaluation judgments completely confidential" came first with an Arithmetical Mean of (4.12) and a Standard Deviation of (0.83), while the paragraph of "The educational supervisor follows up on the evaluation results for social studies teachers" came last with an Arithmetical Mean of (1.83) with a Standard Deviation of (0.67), the Arithmetical Mean of the field of planning as a whole amounted at (2.97) with a Standard Deviation of (1.02), that has a moderate status.

Table (9) Arithmetic Mean And Standard Deviations Of The Role Of Educational Supervisors In Developing The Performance Of Social Studies Teachers On Study Tool As A Whole

\begin{tabular}{|c|c|l|c|c|c|}
\hline Rank & $\begin{array}{l}\text { Field } \\
\text { Number }\end{array}$ & Field & M & SD & Status \\
\hline 1 & 4 & $\begin{array}{l}\text { Classroom } \\
\text { Visits }\end{array}$ & 4.11 & 0.91 & High \\
\hline 2 & 3 & $\begin{array}{l}\text { Relationship } \\
\text { With } \\
\text { Colleagues } \\
\text { And Local } \\
\text { Community }\end{array}$ & 4.00 & 1.27 & High \\
\hline 3 & 1 & Planning & 3.60 & 1.13 & Moderate \\
\hline 4 & 5 & Evaluation & 2.97 & 1.02 & Moderate \\
\hline 5 & 2 & $\begin{array}{l}\text { Teaching } \\
\text { Methods }\end{array}$ & 2.82 & 1.23 & Moderate \\
\hline & \multicolumn{2}{|l}{ The tool as a whole } & $\mathbf{3 . 5 0}$ & $\mathbf{1 . 1 1}$ & Moderate \\
\hline
\end{tabular}

It is evident from Table (9) that the classroom visits field came first, with an Arithmetic Mean of (4.11), and a Standard Deviation of (0.91), followed by the relationship with colleagues and local community field in second place, with an Arithmetic Mean of (4.00), and a Standard Deviation of (1.27), in third place was the field of planning with an Arithmetic Mean of (3.60), a Standard Deviation of (1.13), the field of evaluation came in fourth place with an Arithmetic Mean of (2.97) and a Standard Deviation of (1.02), while the field of teaching methods came in the last place with an Arithmetic Mean of (2.82), and a Standard Deviation of (1.23). Note that the tool as a whole got an Average Arithmetic Mean of (3.50) and a Standard Deviation of (1.11) that has a moderate status.

Second Question: Are there statistically significant impact at the level of significance $(\alpha \leq 0.05)$ in teachers' opinions about the educational supervisor's role in developing the professional performance of social studies teachers attributed to the independent study variables (gender, academic qualification, school level, and years of experience)? 
To answer the question, Arithmetic means, standard deviations, and the T-test for the impact of each variable on the role of educational supervisors in Developing the professional performance of social studies teachers was calculated as follow:

According to the gender variable:

Table (10) Arithmetic Means, Standard Deviations, and T-test According To the Gender Variable

\begin{tabular}{|c|c|c|c|c|c|c|}
\hline Field & Gender & $\mathbf{M}$ & SD & $\mathbf{T}$ & Df & Sig. \\
\hline \multirow[b]{2}{*}{ Planning } & Male & 3.27 & 2.12 & \multirow{2}{*}{0.81} & \multirow{2}{*}{95} & \multirow[b]{2}{*}{.001} \\
\hline & Female & 4.16 & 1.31 & & & \\
\hline \multirow{2}{*}{ Teaching Methods } & Male & 2.85 & 1.17 & \multirow{2}{*}{0.35} & \multirow{2}{*}{95} & \multirow{2}{*}{.000} \\
\hline & Female & 2.91 & 0.82 & & & \\
\hline \multirow{2}{*}{$\begin{array}{l}\text { Relationship With Colleagues And Local } \\
\text { Community }\end{array}$} & Male & 2.87 & 1.12 & \multirow{2}{*}{$\begin{array}{c}- \\
0.75\end{array}$} & \multirow{2}{*}{95} & \multirow{2}{*}{.084} \\
\hline & Female & 2.66 & 1.87 & & & \\
\hline \multirow{2}{*}{ Classroom Visits } & Male & 3.67 & 2.31 & \multirow{2}{*}{1.24} & \multirow{2}{*}{95} & \multirow{2}{*}{.000} \\
\hline & Female & 2.93 & 1.07 & & & \\
\hline \multirow{2}{*}{ Evaluation } & Male & 2.73 & 0.93 & \multirow{2}{*}{$-\overline{9}$} & \multirow{2}{*}{95} & \multirow{2}{*}{.132} \\
\hline & Female & 3.02 & 1.84 & & & \\
\hline \multirow{2}{*}{ Average } & Male & 2.89 & 1.53 & \multirow{2}{*}{0.15} & \multirow{2}{*}{95} & \multirow{2}{*}{.031} \\
\hline & Female & 3.33 & 1.38 & & & \\
\hline
\end{tabular}

Table (10) shows that there is a statistically significant impact at the level of $(\alpha \leq 0.05)$ attributed to the gender variable in the areas of planning and teaching methods in favor of females, and classroom visits in favor of males, while there is no statistically significant impact at the level of $(\alpha \leq 0.05)$ of the gender variable on relations between colleagues and local community and evaluation, as well as, on the tool as a whole. This indicates that males and females both agree that there is a major role for educational supervisors in developing teachers' professional performance of social studies' teachers.

\section{According to the academic qualifications variable:}

Table (11) Arithmetic Means, Standard Deviations, and T-test According To Academic Qualifications Variable

\begin{tabular}{|c|c|c|c|c|c|c|}
\hline Field & $\begin{array}{c}\text { Academic } \\
\text { Qualifications }\end{array}$ & M & SD & $\mathbf{T}$ & df & Sig. \\
\hline \multirow{2}{*}{ Planning } & Undergraduate & 2.34 & 1.51 & \multirow{2}{*}{0.66} & \multirow{2}{*}{95} & \multirow[b]{2}{*}{.0} \\
\hline & Postgraduate & 3.98 & 0.85 & & & \\
\hline \multirow{2}{*}{$\begin{array}{l}\text { Teaching } \\
\text { Methods }\end{array}$} & Undergraduate & 2.17 & 0.93 & \multirow{2}{*}{0.10} & \multirow{2}{*}{95} & \multirow{2}{*}{.000} \\
\hline & Postgraduate & 4.03 & 0.83 & & & \\
\hline \multirow{3}{*}{$\begin{array}{c}\text { Relationship } \\
\text { With } \\
\text { Colleagues } \\
\text { And Local } \\
\text { Community }\end{array}$} & Undergraduate & 2.97 & 1.03 & \multirow[b]{2}{*}{ 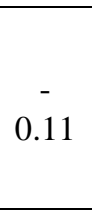 } & \multirow[b]{2}{*}{95} & \multirow[b]{2}{*}{.232} \\
\hline & Postgraduate & 1.87 & 1.14 & & & \\
\hline & Undergraduate & 3.32 & 2.17 & & 95 & .351 \\
\hline
\end{tabular}




\begin{tabular}{|c|c|c|c|c|c|c|}
\hline $\begin{array}{c}\text { classroom } \\
\text { visits }\end{array}$ & Postgraduate & 2.17 & 2.42 & - & & \\
\cline { 1 - 5 } Evaluation & Undergraduate & 2.83 & 0.91 & \multirow{2}{*}{0.28} & \multirow{2}{*}{95} & \multirow{2}{*}{.000} \\
\cline { 2 - 7 } & Postgraduate & 2.03 & 0.63 & & \\
\hline \multirow{2}{*}{ Average } & Undergraduate & 2.73 & 1.43 & 0.14 & \multirow{2}{*}{95} & .211 \\
\cline { 2 - 6 } & Postgraduate & 2.82 & 1.17 & & \\
\hline
\end{tabular}

Table (11) shows that there is a statistically significant impact at the level of $(\alpha \leq 0.05)$ attributed to the academic qualifications variable in the areas of planning and teaching methods in favor of postgraduate degree holders, and evaluation in favor of undergraduate degree holders, while there is no statistically significant impact at the level of $(\alpha \leq 0.05)$ of the academic qualifications variable on classroom visits and relations between colleagues and local community and, as well as, on the tool as a whole. This indicates that social studies teachers of different academic qualifications agree that there is no major role for educational supervisors in developing their professional performance.

\section{According to To School Level variable:}

Table (12) Arithmetic Means, Standard Deviations, and T-test According To School Level Variable

\begin{tabular}{|c|c|c|c|c|c|c|}
\hline Field & School Level & M & SD & $\mathbf{T}$ & df & Sig. \\
\hline \multirow{2}{*}{ Planning } & Primary & 3.26 & 0.83 & \multirow{2}{*}{-0.09} & \multirow{2}{*}{95} & \multirow{2}{*}{.010} \\
\hline & Secondary & 2.64 & 0.92 & & & \\
\hline \multirow{2}{*}{ Teaching Methods } & Primary & 2.27 & 1.01 & \multirow{2}{*}{0.71} & \multirow{2}{*}{95} & \multirow{2}{*}{.300} \\
\hline & Secondary & 1.87 & 0.93 & & & \\
\hline \multirow{2}{*}{$\begin{array}{c}\text { Relationship With Colleagues } \\
\text { And Local Community }\end{array}$} & Primary & 3.83 & 1.22 & \multirow{2}{*}{-0.70} & \multirow{2}{*}{95} & \multirow{2}{*}{.031} \\
\hline & Secondary & 2.13 & 1.92 & & & \\
\hline \multirow{2}{*}{ Classroom Visits } & Primary & 2.87 & 0.74 & \multirow{2}{*}{-0.08} & \multirow{2}{*}{95} & \multirow{2}{*}{.301} \\
\hline & Secondary & 1.66 & 0.82 & & & \\
\hline \multirow{2}{*}{ Evaluation } & Primary & 3.22 & 1.16 & \multirow{2}{*}{0.24} & \multirow{2}{*}{95} & \multirow{2}{*}{.213} \\
\hline & Secondary & 2.63 & 0.92 & & & \\
\hline \multirow{2}{*}{ Average } & Primary & 3.09 & 0.99 & \multirow{2}{*}{0.02} & \multirow{2}{*}{95} & \multirow{2}{*}{.312} \\
\hline & Secondary & 2.17 & 1.10 & & & \\
\hline
\end{tabular}

Table (12) shows that there is a statistically significant impact at the level of $(\alpha \leq 0.05)$ attributed to the school level variable in the areas of planning and relationship with colleagues and the local community in favor of primary schools, while there is no statistically significant impact at the level of $(\alpha \leq 0.05)$ of the school level variable on classroom visits, teaching methods, and evaluation, as well as, on the tool as a whole. This indicates that social studies teachers of different school levels agree that there is no major role for educational supervisors in developing their professional performance. 


\section{According to years of experience variable:}

Table (13) Arithmetic Means, standard deviations, and T-test according to the Years of Experience Variable

\begin{tabular}{|c|c|c|c|c|c|c|}
\hline Field & Years of Experience & $\mathbf{M}$ & SD & $\mathbf{T}$ & df & Sig. \\
\hline \multirow[b]{2}{*}{ Planning } & 10 years and less & 2.74 & 1.12 & \multirow[b]{2}{*}{0.21} & \multirow[b]{2}{*}{95} & \multirow[b]{2}{*}{.000} \\
\hline & $\begin{array}{c}\text { More than } 10 \\
\text { years }\end{array}$ & 3.66 & 0.91 & & & \\
\hline \multirow[b]{2}{*}{ Teaching Methods } & 10 years and less & 3.04 & 1.02 & \multirow[b]{2}{*}{0.15} & \multirow[b]{2}{*}{95} & \multirow[b]{2}{*}{.001} \\
\hline & $\begin{array}{c}\text { More than } 10 \\
\text { years }\end{array}$ & 3.26 & 0.87 & & & \\
\hline \multirow{2}{*}{$\begin{array}{c}\text { Relationship With } \\
\text { Colleagues And Local } \\
\text { Community }\end{array}$} & 10 years and less & 3.62 & 1.17 & \multirow[b]{2}{*}{0.37} & \multirow[b]{2}{*}{95} & \multirow[b]{2}{*}{.000} \\
\hline & $\begin{array}{c}\text { More than } 10 \\
\text { years }\end{array}$ & 2.97 & 1.54 & & & \\
\hline \multirow[b]{2}{*}{ Classroom Visits } & 10 years and less & 2.87 & 1.77 & \multirow[b]{2}{*}{0.51} & \multirow[b]{2}{*}{95} & \multirow[b]{2}{*}{.061} \\
\hline & $\begin{array}{c}\text { More than } 10 \\
\text { years }\end{array}$ & 2.23 & 1.26 & & & \\
\hline \multirow[b]{2}{*}{ Evaluation } & 10 years and less & 2.76 & 0.81 & \multirow[b]{2}{*}{0.14} & \multirow[b]{2}{*}{95} & \multirow[b]{2}{*}{.073} \\
\hline & $\begin{array}{c}\text { More than } 10 \\
\text { years }\end{array}$ & 2.99 & 0.67 & & & \\
\hline \multirow[b]{2}{*}{ Average } & 10 years and less & 3.01 & 1.12 & \multirow[b]{2}{*}{0.64} & \multirow[b]{2}{*}{95} & \multirow[b]{2}{*}{.017} \\
\hline & $\begin{array}{c}\text { More than } 10 \\
\text { years }\end{array}$ & 3.02 & 1.05 & & & \\
\hline
\end{tabular}

Table (13) shows that there is a statistically significant impact at the level of $(\alpha \leq 0.05)$ attributed to the years of experience variable in the areas of planning, teaching methods, and relationship with colleagues and the local community in favor of the category of (more than 10) years, while there is no statistically significant impact at the level of $(\alpha \leq 0.05)$ of the years of experience variable on classroom visits and evaluation, as well as, on the tool as a whole. This indicates that social studies teachers of different years of experience agree that there is a major role for educational supervisors in developing their professional performance.

\section{Conclusion}

The results showed that the classroom visits came first with a high degree, and this may be attributed to the fact that the classroom visits are considered one of the tasks of the educational supervisor in Jordan which is considered routine and a method of evaluation despite the researcher's conviction that it does not fulfill its objectives as required, as most of the time the supervisor visits only as a functional task despite the call to find other supervisory methods. In the second place came the field of relations with colleagues and the local community with a high degree as well, where supervisors focus on human relations with teachers so that the relationship becomes open between them, by sitting with them before heading to the classroom and after the supervisory visit, as well as the educational supervisor 
does not neglect the development plan in the school that interests. As for the advent of planning in third place, which came with a medium degree, this is since the Ministry of Education is still following the central administrative pattern, and the supervisor has nothing to do except implementation, although planning is the basis of the work of the educational supervisor and teacher and a major part of their work. In the fourth place came the field of evaluation with a medium degree, attributed to the fact that the majority of educational supervisors do not have higher qualifications in the measurement and evaluation specialization, but rather that the number is very limited, as Jordanian universities grant this specialization only at the level of postgraduate studies and the majority of courses cover the theoretical side only, so the supervisors 'experience educators are weak in this area. As for the field of teaching methods, which came in the fifth rank with a medium degree as well, as a result of the fact that classroom visits are not usually at the beginning of the classroom at the time needed by the teacher, as the teacher needs these visits, in the beginning, to help in developing the educational plan for the subjects and analyzing the curricula and usually the supervisor depends on in that on the school principal.

The results also showed that there is an existence of a statistically significant impact attributed to the gender variable in the fields of planning and teaching methods in favor of females, and in the field of classroom visits in favor of males, and the absence of a statistically significant impact of the gender variable on the field of relations between colleagues and the community as well on the field of evaluation, and the reason for this may be that females are usually more concerned and understanding the importance of educational supervision to enhance their performance, and therefore, they are more committed to attending training courses and following up educational developments programs. The results also showed the existence of a statistically significant impact attributed to the academic level variable in the fields of planning and teaching methods in favor of postgraduate degrees holders, and on evaluation in favor of undergraduate degrees holders, but it did not show an effect on the fields of classroom visits and relations with colleagues and the local community, this may be for the reason that the educational level does not constitute an important factor effective in changing the teacher's assessments of the role of the educational supervisor, and this means that a teacher who holds an undergraduate degree may quickly acquire his experience and becomes equal to that of a post graduated. There is also a statistically significant effect attributable to the school level variable in the fields of planning and relations with colleagues and the local community in favor of primary schools, and there is no statistically significant impact attributable to the school level variable on teaching methods, classroom visits, and evaluation, as teachers in primary schools are usually less experienced in 
assessing the importance of educational supervisor. Finally, the study showed that there is a statistically significant effect attributed to the years of experience variable on the fields of planning, teaching methods, relations with colleagues and the local community in favor of years of experience (more than 10 years) and there is no effect of the years of experience variable on classroom visits and evaluation, the reason for this may be that teachers with higher experience, may have sufficient experience and have more knowledge of the teaching, technical and administrative tasks required of educational supervisors.

\section{Recommendations}

In light of the conclusions, the study recommends that there is a necessity for the Ministry of Education for reviewing and reinforce the educational supervision system and increase the quality of education, thus, a new educational supervision model based on multiple data sources based on guidance should be developed and rapidly adapted to compete with the rapid changes occurring in the educational system, as well as, technological and educational system as a whole. And to achieve the objectives of supervision, inspections should be carried out by professionally competent personnel by providing adequate time and guidance services through effective communication taking the principle of equality into account. As well as, the social educational supervisor should act in an open, honest, and fair manner during the supervision process and create an atmosphere of positive communication with the teachers as the communication between the educational supervisors or school administrators and the teachers must be constructive and positive during the supervision process where it shall reduce the psychological pressure on teachers and that supervision can be extended to include a longer period, rather than restricting it to a one-hour course. Also, the study recommends the necessity of planning, implementing, and evaluating educational supervision in a participatory manner with the participation of teachers where they need a good understanding of the field and tasks of supervision, especially educational supervision so that the supervisor is required to master the principles and techniques in addition to the professional practice of educational supervision. Supporting the educational supervisor of the teacher, such as recognition of merit and competence to achieve psychological satisfaction at work by giving supervisors appreciation and material and non-material support, as teachers 'satisfaction will have a broad impact on improving professional capabilities and teachers' performance. Finally, Supervisors of social studies should receive continuous mandatory in-service training to equip them with supervisory competencies to develop teaching practices among teachers. 


\section{References:}

1. Abdul Hadi, Judeh (2002). Educational supervision, concepts, and methods. The Scientific House and the Culture House for Publication and Distribution. Amman, Jordan.

2. Abu Gharbia, Iman (2009). Educational supervision: concepts, reality, and prospects. ( $1^{\text {st }}$ ed.). Dar Al-Bedayeh and Almostaqbal publishing house. Amman. Jordan

3. Al-Ajmai, Muhammad (2008). School administration and the requirements of the era. The New University House. Alexandria. Eygpt.

4. Al-Aklabi, F. bin-Abdullah (2001). Attitudes of educational supervisors towards the teaching profession, The Educational Journal. Vol.15 (59) pp. 67-96.

5. Alarcao, I. (2009). Teacher Education and Supervision: a new scope. Educational Sciences Journal. Vol. 8. pp. 109-118.

6. Al-Asadi, Ibrahim (2003). Educational supervision. ( $1^{\text {st }}$ ed.). House of Science and Culture for Publication and Distribution. Cairo. Egypt.

7. Al-Badri, Tariq (2008). Applications and concepts in educational supervision. ( ${ }^{\text {th }}$ ed.). Dar Al-Fikr for Publishing. Amman. Jordan.

8. Al-Dossary, Bader (2008). The role of the educational supervisor in raising the efficiency of the job performance of art education teachers in the primary stage from the teachers' point of view. Unpublished master's degree thesis. College of Education. King Saud University. Riyadh. Saudi Arabia.

9. Al-Hajri, A. Saeed (2007). The role of educational supervisors in developing the performance of Islamic education teachers in the State of Kuwait, from the teachers' point of view. Unpublished Master thesis, Amman Arab University for Graduate Studies. Amman. Jordan.

10. Al-Hamdoun, M. Nazzal (2016). The Role of Physical Education Supervisors in Developing School Sports for Education Directorates from the Teachers' Point of View in Mafraq Governorate, Journal of the Association of Arab Universities for Education and Psychology, Vol. 14(2), Damascus, Syria, pp. 84-109.

11. Al-Khatib, Ibrahim, and Al-Khatib, Amal (2003). Educational supervision, its philosophy, methods, and applications ( $1^{\text {st }}$ ed.). Kandil House for Publishing and Distribution. Amman, Jordan.

12. Al-Khatib, Radaah. Al-Khatib, Ahmed. Al-Farah, Wajih (2002). Educational Administration and Supervision (Modern Trends) $\left(1^{\text {st }}\right.$ ed.). Dar Al-Amal publications. Amman, Jordan.

13. Al-Maghidi, Hassan (2001). Effective educational supervision. AlRashed Library. Riyadh, Saudi Arabia. 
14. Al-Masad, Mahmoud (1986). Educational Administration and Supervision, Reality, and Ambition. Dar Al-Amal. Irbid. Jordan.

15. Al-Moizri, Abd Allah (2001). The role of the educational supervisor in developing teaching skills. Unpublished Master's thesis. King Saud University. Riyadh, Kingdom of Saudi Arabia.

16. Al-Shaddadi, Muhammad (2009). The role of the educational supervisor in improving the educational performance of teachers with learning difficulties in Al-Madinah Al-Munawwarah region from the teachers' viewpoint. Unpublished master's degree thesis. College of Education - Umm Al-Qura University. Saudi Arabia.

17. Atwi, Jawdat (2008). Educational administration and educational supervision: their origins and application. Dar Al-Elmeya and House of Culture for publication and distribution. Amman, Jordan.

18. Ayesh, Ahmad (2008). Applications in educational supervision. ( $1^{\text {st }}$ ed.). Dar Almaseera. Amman. Jordan.

19. Delandshere, G. (2002). Assessment as inquiry. Teachers' College Record. 104 (7). pp. 1461-1484.

20. Fenish, Ahmadou, and Zidan, Mohammed (2000). Technical and educational guidance. United Book House. Beirut, Lebanon.

21. Ferguson, T. (2004). The role of the educational supervisor in improving the performance of teachers of math at the elementary stage. NY Management Review. 59(3), pp. 173-210.

22. Fitzgibbons, D. (2005). Transforming business and education: The challenge to organizations and educators. Organization Development Journal, 21(4).

23. Giannola, D. (2005). An inclusion resource for student teachers, cooperating teachers, and supervisors. Teaching \& Learning Journal. Vol. 19(2). pp. 77-99.

24. Hassan, Mohamed (2003). The relationship between the teachers' awareness of the role of the director and mentor in the educational field in encouraging them to innovate and their use of methods to enhance the innovative behavior of students. The Educational Journal, Vol. 17 (67). pp. 13-94.

25. Hamida, Fathy (2012). The role of the educational supervisor in improving the performance of kindergarten teachers. Damascus University Journal, Vol.52. pp. 30-56.

26. Homana, G. (2007). Research in Services Learning. The Center for Information on Civic Learning \& Engagement. The University of Maryland. The USA.

27. Hussein, Salama, and Abu Al-Wafa, Jamal (2008). School and classroom administration. The New University House. Alexandria. Egypt. 
28. Justice, L. (2007). Clinical approaches to emergent literacy intervention: emergent and early literacy. Plural Publishing. San Diego.

29. Khawaldeh, Nasser (2002). The role of the Islamic Education Supervisor in improving the performance of Islamic education teachers in basic schools from the teachers' viewpoint. Studies Journal. Vol. 29 (2), pp. 379-364.

30. Madanat, Kamal. Ougeni, Barzeh (2002). The interests of educational supervision in improving the performance of teachers ( $1^{\text {st }}$ ed.). House of Culture for Publishing and Distribution. Amman, Jordan.

31. Obaidat, Thouqan. Abu Al Seemed, Suhaila (2007). Modern strategies in educational supervision. Dar Al-Fikr for Publishing and Distribution. Amman. Jordan.

32. Qazak, Ibrahim. (2006). The role of the educational supervisor in improving the professional growth of the first three grade teachers in Irbid Governorate. Unpublished Master's thesis. Yarmouk University. Irbid. Jordan.

33. Siam, AbdulSalam (2007). The role of educational supervision methods in developing the professional performance of teachers in secondary schools in Gaza governorate. Unpublished master's degree thesis. College of Education. Islamic University. Gaza, Palestine.

34. Sharia, H. Muhammad (2019). Educational Supervision in the Directorate of Education for the Taibeh and Wasatiya Districts in Irbid Governorate and its Role in Improving the Performance of Teachers from the Teachers' Point of View. The Arab Journal of Educational and Psychological Sciences, Vol. 9. pp. 109-136.

35. Tim, Hassan (2009). The reality of supervisory practices of the educational supervisor in the governorates of northern Palestine from the point of view of male and female teachers. An-Najah University Journal for Research - Humanities -. Vol. 32. pp. 180-201. 